\title{
Influences of Gender on Intravenous Nalbuphine Actions After Major Abdominal Surgery: A Multicenter Study
}

\author{
Amany E. Ayad - Ossama H. Salman · Ahmed Mokhtar Fathy Ibrahim • \\ Waleed A. M. Al-Taher - Adel M. Mishriky · Joseph V. Pergolizzi · \\ Omar Viswanath · Ivan Urits · Martina Rekatsina $\cdot$ John F. Peppin · \\ Antonella Paladini · Giustino Varrassi
}

Received: April 22, 2021 / Accepted: May 27, 2021 / Published online: June 10, 2021

(c) The Author(s) 2021

\section{ABSTRACT}

Introduction: Nalbuphine, a synthetic kappaopioid receptor (KOR) agonist and a partial $\mu$ opioid receptor (MOR) antagonist, has been

A. E. Ayad

Department of Anesthesia ICU and Pain, Cairo

University, Cairo 11566, Egypt

e-mail: amanymounir@kasralainy.edu.eg

\section{O. H. Salman}

Department of Anesthesiology, South Valley

University, Qena 83511, Egypt

e-mail: ossamas@hotmail.com

A. M. F. Ibrahim

Department of Anesthesiology, Assiut University, Assiut 71515, Egypt

e-mail: amfimm@yahoo.com

W. A. M. Al-Taher

Department of Anesthesiology, Ain Shams

University, Cairo 11566, Egypt

e-mail: waleedaltaher@hotmail.com

A. M. Mishriky

Department of Community Medicine, Suez Canal

University, Ismailia 41511, Egypt

e-mail: adel.mishriky@gmail.com

J. V. Pergolizzi

NEMA Research Group, Research and Development,

Naples, FL 34101, USA

e-mail: jpjmd@msn.com

O. Viswanath

Department of Anesthesiology, University of used for years as an effective analgesic. It has been shown to have a better safety profile than morphine. Considering the long history of use of this drug, it is interesting that only a limited amount of information exists on how gender

Arizona, Phoenix, AZ 85003, USA

e-mail: viswanoy@gmail.com

I. Urits

Department of Anesthesia, Critical Care and Pain Medicine, Beth Israel Deaconess Medical Center, Harvard Medical School, Boston, MS, USA e-mail: ivanurits@gmail.com

\section{Rekatsina}

Whipps Cross Hospital, Barts Health NHS Trust, London, UK

e-mail: martina.rekatsina@nhs.net

\section{J. F. Peppin}

College of Osteopathic Medicine, Pikeville

University, Pikeville, KT, USA

e-mail: johnpeppin@msn.com

\section{A. Paladini}

Department of MESVA, University of L'Aquila, 67100 L'Aquila, Italy

e-mail: antopaladini@gmail.com

G. Varrassi $(\bowtie)$

Research and Development, Paolo Procacci

Foundation, via Tacito 7, 00193 Rome, Italy

e-mail: giuvarr@gmail.com 
differences influence nalbuphine responses. In this randomized double-blind comparative trial after major abdominal surgery, the analgesic effects of two doses of continuous intravenous infusion of nalbuphine were evaluated based on gender.

Methods: Enrolled patients were divided into four groups (two females and two males with 32 patients in each group). Two of them (groups A1 and A2), one male and one female, received postoperative continuous intravenous infusions of nalbuphine at $2 \mathrm{mg} / \mathrm{h}$ via patient-controlled analgesia (PCA). Each patient had the potential of receiving a rescue bolus of $1 \mathrm{mg}$ of nalbuphine with a lock out time of $15 \mathrm{~min}$. The other two groups (groups B1 and B2) received half the infusion dose, $1 \mathrm{mg} / \mathrm{h}$, and half the nalbuphine rescue dose with the PCA pump, $0.5 \mathrm{mg}$ maximum every $15 \mathrm{~min}$ as needed. Patients' vital signs, numerical pain rating scores, rescue nalbuphine, and incidence of side effects were assessed immediately after the operation, and every $3 \mathrm{~h}$ during the first $12 \mathrm{~h}$.

Results: Nalbuphine $2 \mathrm{mg} / \mathrm{h}$ dosing led to significantly lower pain scores amongst females compared to males at 6,9 , and $12 \mathrm{~h}$; while the $1 \mathrm{mg} / \mathrm{h}$ infusion pain scores were only lower at the 9-h time period. Females receiving the nalbuphine $2 \mathrm{mg}$ dose at $6 \mathrm{~h}$, and the $1 \mathrm{mg}$ dose at 6, 9, and 12-h measurements needed significantly lower doses of rescue nalbuphine. Females on the $1 \mathrm{mg}$ dose experienced significantly more nausea, vomiting, and sedation at the 6-, 9-, and 12-h measurement times. In the multivariate analysis, female gender was a negative predictor at all measurement times.

Conclusions: The current study supports the hypothesis that although nalbuphine was found to be an effective and well-tolerated analgesic after major abdominal surgery, females were statistically more responsive than males.

Trial Registration: The study was registered at the Pan African Clinical trials Registry PACTR201304000486309, and approved for the Ethical aspects.

Keywords: Opioids; Agonist-antagonist; Nalbuphine; Gender effect

\section{Key Summary Points}

Nalbuphine is an opioid introduced in the clinical use several years ago, which may be used in postoperative pain management.

There are few data on the responses to the use of that medicine, comparing its efficacy in the different genders.

This study is focused on the analysis of the effects of nalbuphine on postoperative pain management in the two different genders, at two different dosages.

The results clearly show that females are more sensitive than males to the effects of nalbuphine, when administered for postoperative pain treatment.

\section{DIGITAL FEATURES}

This article is published with digital features, including a summary slide, to facilitate understanding of the article. To view digital features for this article go to https://doi.org/10.6084/ m9.figshare.14686863.

\section{INTRODUCTION}

Opioids are routinely used to treat post-operative moderate to severe pain $[1,2]$. Optimizing the utilization of opioids to improve outcomes and reduce side effects, would make a marked improvement in the practice of acute pain management. While evidence suggests that gender is a factor that may influence the assessment and management of pain, only a limited amount of information exists on gender difference and how those differences influence the response to analgesic medications [3]. A systematic review and meta-analysis of 50 studies using patient-controlled analgesia (PCA) opioids suggests that these different responses from women experiencing better pain relief 
compared to men are seen routinely [4]. However, this metanalysis did not differentiate $\mu$ opioid receptors (MOR), $\kappa$-opioid receptors (KOR), or the mixed agonist/antagonist opioids, such as nalbuphine [4].

Nalbuphine was patented in 1963 and approved for use in the United States in 1979 and is a synthetic mixed agonist/antagonist opioid [5]. Its analgesic action occurs predominantly through stimulation of KOR [5]. It has been previously shown, in a study using a single-dose injection, to have a greater analgesic effect in females [6]. In this study's conclusion, it was suggested that "the antianalgesic effect of nalbuphine suggests avoidance of its routine use for postoperative analgesia in men" although the authors indicated more research was needed [6].

Opioid receptors are widely expressed in the entire body, and especially in the central nervous system where they mediate analgesic action and modulate numerous endogenous functions [5]. These receptors are classic G-protein coupled receptors and can form dimers with other G-protein coupled receptors. These dimers provide "another layer of complexity" in signaling and modulation [7]. MOR and KOR heterodimers form in both humans, and in animal models, and may relate to the differences seen between males and females, especially when agonist/antagonist agents are used, e.g., nalbuphine. Studies in animal models have found MOR-KOR heterodimers in the spinal cord of females to be almost five times more than those of males [8]. However, as with all pain, visceral pain is extremely complex, both in acute, postsurgical, and chronic forms $[9,10]$. Multiple receptors systems are involved, but the finding of increased MOR/KOR heterodimers in female animal models and the clinical findings of improved pain relief using the agonist/antagonist nalbuphine is intriguing. Pain from major abdominal surgery is mostly a nociceptive somatic and visceral pain, and KOR are associated with visceral pain [11]. If it is true that human females have higher MOR/KOR heterodimer density in the spinal cord and that these heterodimers play a significant role in the development of visceral pain, this could suggest that the visceral pain model would be a better model to evaluate gender differences.

Therefore, this randomized double-blind comparative clinical trial was designed to compare the effects of two doses of nalbuphine using a continuous intravenous infusion for postoperative pain control after major abdominal surgery to evaluate the differences between male and female patients.

\section{METHODS}

This multi-center clinical trial was carried out in two centers in Egypt, and in accordance with the Declaration of Helsinki [https://www.wma. net/policies-post/wma-declaration-of-helsinkiethical-principles-for-medical-research-involvinghuman-subjects/]. Prior to patients' enrollment, the study was registered at the Pan African Clinical trials Registry with the number PAC TR201304000486309, and the study protocol, amendments, and informed consent forms were reviewed and approved by the institutional review boards of both centers [https:// www.who.int/clinical-trials-registry-platform/net work/primary-registries/pan-african-clinical-trialsregistry-pactr] (Ethical Committee/Medical council of Dar Al Fouad Hospital, and Ethical Committee of Quena University Hospitals/ South Valley University ID; 5433-03). The trial design was a randomized double-blinded prospective study. All patients provided signed informed consent prior to being included in the study. The informed consent included the use of anonymized patient information and data for publication.

\section{Sample size}

The sample size was calculated to detect the difference between the mean change in the numerical pain rating score between women and men during the measurement periods (women $X_{1}=1 \pm 1.2$, men $X_{2}=0.1 \pm 1.2$ ) according to Gear et al. [12], with a 95\% level of confidence $(\alpha$ error $=5 \%)$, and a study power of $80 \%$ ( $\beta$ error $=20 \%$ ). Using the equation for the difference between two means [13], the estimated sample size was 28 subjects per group. 
After adjustment for a dropout rate of $10 \%$, the sample size was estimated as 32 patients per group.

\section{Criteria for participation in this clinical trial}

Sixty-four male and sixty-four female patients, aged 18-65 years old, were enrolled in this study. Their ASA status was I-III and patients had been scheduled for elective major abdominal surgery.

Patients with a definite diagnosis of chronic pain syndrome, psychiatric disorders, or substance use disorder, patients who used sedatives, antiemetics, or anti-pruritic agents within $24 \mathrm{~h}$ before operation, patients with a definite diagnosis of esophageal reflux syndrome, and patients with known allergies to opioids were excluded from the study. Intraoperative fentanyl use $>3 \mu \mathrm{g} / \mathrm{kg}$, surgery that lasted $>4 \mathrm{~h}$ or $<2 \mathrm{~h}$, laparoscopic surgery, and gender-related major abdominal operations, e.g., prostatectomy and hysterectomy, were excluded. Patients with a limited understanding of the procedure or the use of PCA were also excluded.

During the preoperative visit, patients were taught how to use the Numerical Rating Scale (NRS) to express their pain [14]. The night before the operation, the use of PCA pump was explained to patients, telling them to use it whenever they felt pain over 3 (moderate or severe pain) based on the NRS. Another goal of this training was to help patients overcome societal beliefs that it is more admirable to bare pain without complaint or treatment (especially with patients coming from rural areas such as Qena).

Pre-operatively, an intravenous line was placed in a peripheral vein and fluids were applied in a "to keep open rate", or $10 \mathrm{ml} / \mathrm{h}$. Ondansetron $4 \mathrm{mg}$ was given intravenously as per standard protocol. Patients were transferred to the operating room, where fentanyl $1 \mu \mathrm{g} / \mathrm{kg}$ was administered 5-10 min before tracheal intubation. Anesthesia was induced with propofol and atracurium and maintained with isoflurane in an oxygen/air mixture according to our standard anesthesia protocol. During surgery, analgesia was assured by giving additional intravenous fentanyl increments titrated to ensure adequate analgesia of a total dose of no more than $3 \mu \mathrm{g} / \mathrm{kg}$. In the Post Anesthesia Care Unit (PACU), after the return of full consciousness, patients were questioned about the presence of pain and asked to rate their pain intensity using the NRS. Then patients received a continuous infusion of nalbuphine $(20 \mathrm{mg}$, ampoules by Amoun Pharmaceuticals, Egypt) diluted in normal saline, using a silicone balloon pump infuser (Accufuser Plus (Woo Young Medical Co., Ltd, China) and a PCA single-use disposable pump. The infuser provided both continuous and bolus infusions and held a volume of $100 \mathrm{ml}$ with a potential maximal basal rate of $2 \mathrm{ml} / \mathrm{h}$ and a bolus rate of $1 \mathrm{ml}$ with a lockout time of $15 \mathrm{~min}$. The drug concentrations of both continuous and bolus doses were adjusted by group depending on the study protocol. Male and female patients were randomized within each group to receive one of the two study analgesic regimens. A web-based computer-generated randomization process, automatically recording number and assignments, was used for the randomization. A researcher, separate and blinded from the main investigator, was responsible for the process of randomizing patients. This researcher initiated the order to the clinical pharmacist who prepared the study drug dose in the Accufuser pump and labeled a tag indicating "Nalbuphine Research", the patient's name and medical number, and no further data.

\section{Group A: $2 \mathrm{mg} / \mathrm{h}$ PCA basal rate}

This group included the first and second subgroups (male and female). They received a continuous infusion of $2 \mathrm{mg} / \mathrm{h}$ intravenous nalbuphine.

Group A1, nalbuphine $2 \mathrm{mg}$ (32 male patients) Patients received a continuous background intravenous infusion of nalbuphine at $2 \mathrm{mg} / \mathrm{h}$. If the pain score was higher than $3 / 10$, patients pressed the PCA button to receive the PCA bolus of $1 \mathrm{mg}$ of nalbuphine, with a lockout time of $15 \mathrm{~min}$.

Group A2, nalbuphine $2 \mathrm{mg}$ (32 female patients) Patients received the same identical treatment as Group A1.

Group B: $1 \mathrm{mg} / \mathrm{h}$ PCA basal rate 
Group B1, nalbuphine $1 \mathrm{mg}$ (32 male patients) Patients received a continuous background intravenous infusion of nalbuphine at $1 \mathrm{mg} / \mathrm{h}$. If the pain score was higher than $3 / 10$, patients pressed the PCA button to receive the PCA bolus, as previously taught of $0.5 \mathrm{mg}$ of nalbuphine, with a lockout time $15 \mathrm{~min}$.

Group B2, nalbuphine $1 \mathrm{mg}$ (32 female patients) Patients received the same identical treatment as group B1.

\section{Collected data}

1. Baseline NRS scores/ratings We monitored baseline pain NRS scores in the PACU immediately after surgery, and then at 3 hourly intervals for the first $12 \mathrm{~h}$ for a total of five pain measurements.

2. Analgesia The cumulative nalbuphine consumption in milligrams and the total number of rescue nalbuphine doses used was recorded.

3. Vital signs Hemodynamic variables were monitored, i.e., pulse rate and blood pressure, in the PACU immediately after surgery, and then at 3-h intervals for the first $12 \mathrm{~h}$. Hypotension (defined as a drop in the systolic/diastolic blood pressure more than $20 \%$ from baseline), bradycardia (defined as a drop in heart rate of more than $20 \%$ from baseline) were recorded. Respiratory depression was defined as a respiratory rate of less than 8 breaths/min.

4. Adverse events We recorded the incidence of any adverse event at 3-h intervals for the first $12 \mathrm{~h}$, e.g., nausea/vomiting, dizziness, sedation, dysphoria, itching, and urine retention. All adverse events or side effects were managed as per our standard protocols.

\section{STATISTICAL ANALYSIS}

Data entry and statistical analysis was done using SPSS 20.0 statistical software package. Quantitative continuous data were compared using Student's $t$ test comparisons between two independent groups or the non-parametric
Mann-Whitney test as appropriate. Categorical variables were compared using Chi-square test or Fisher's exact test as suitable. In order to identify independent predictors impacting pain scores, multiple linear regression analysis was used after testing for normality and homoscedasticity, and analysis of variance for the full regression models were done. Statistical significance was considered at $p$ value $<0.05$.

\section{RESULTS}

All enrolled patients completed the study except for one 19-year-old female patient in group B who declined after giving her written consent. Figure 1 is a Consort flow diagram representing the progress of patients through the trial [15].

At the admission to the study, there were no relevant differences between male and female patients as demographics (Table 1). There were no significant differences between group A and $\mathrm{B}$, regarding their BMI, co-morbidities, or medication intake. Table 2 shows the type of surgery received by the patients and the ASA status.

Tables 3 and 4 report the baseline pain, at the end of surgery, in the four groups of patients. More female patients had severe pain at baseline, but the difference was not statistically significant. While group B2 showed a significantly higher pain score for patients having mild pain, when compared to group B1.

The only major difference was the intake of postoperative nalbuphine, which was significantly higher in both male groups when compared to female (Table 5). Comparison of pain scores by gender and nalbuphine cumulative dosage demonstrates decreasing trends over time (Fig. 2). In group A, the pain scores were significantly lower among female patients (group A2) at 6, 9, and 12-h measurement times. Group B2 had a significantly lower pain score only at the 9-h measurement.

There was a decreasing trend in the use of rescue nalbuphine over time in all the four groups (Fig. 3). Group A2 patients needed lower doses of rescue nalbuphine, but the difference was statistically significant only at the 6-h measurement time. Group B2 patients needed 


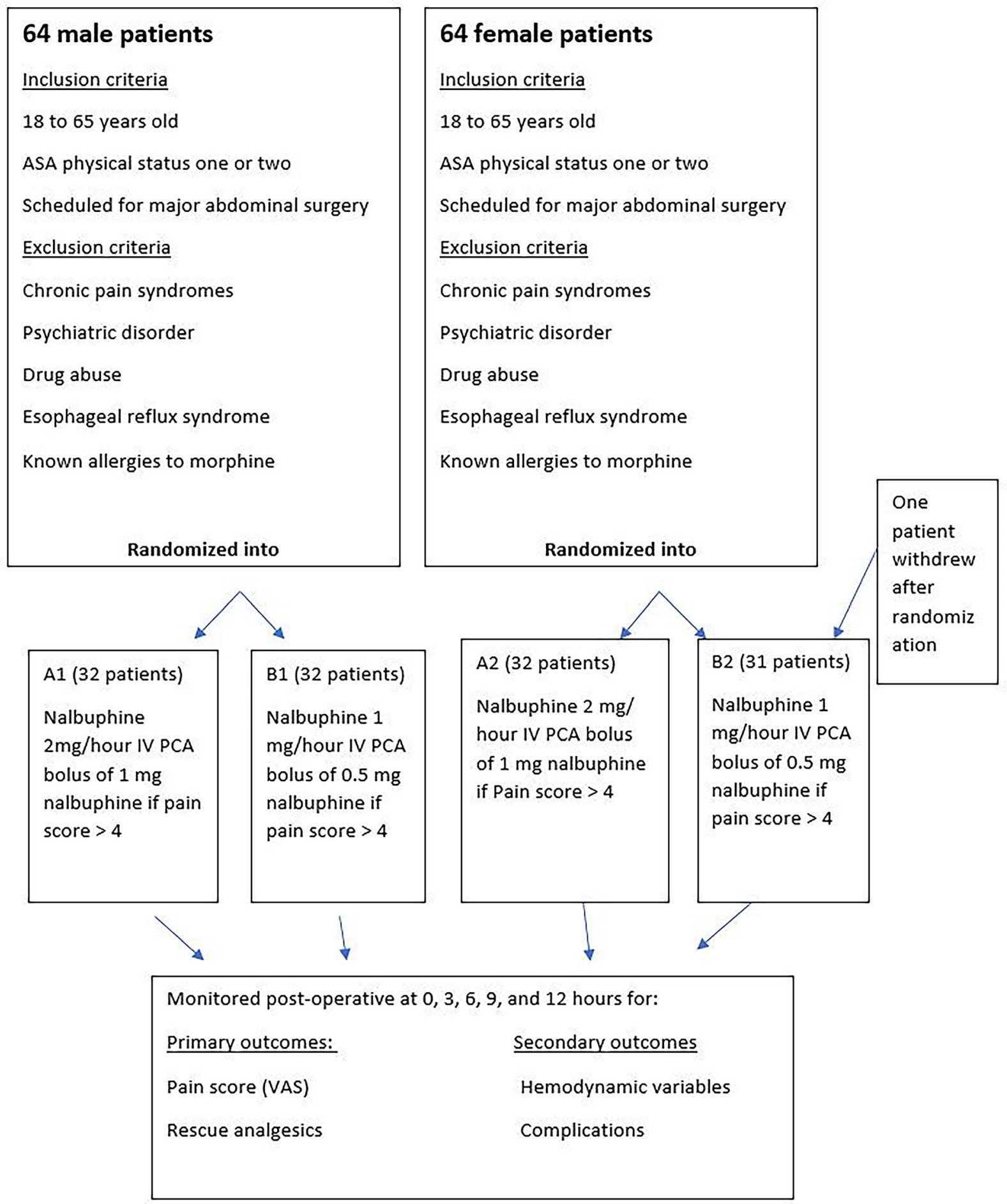

Fig. 1 Consort flow diagram representing patients flow during the trial

significantly lower total doses at 6, 9, and 12-h measurement times. Group A2 patients utilized $26.50 \mathrm{mg} \pm 1.30$, versus $27.59 \mathrm{mg} \pm 1.93$ in group A1 $(p=0.010)$. In group B, females (group B2) utilized $16.45 \pm 1.65 \mathrm{mg}$ versus $18.44 \pm 4.13 \mathrm{mg}$ in group B1 $(p=0.016)$. 
Table 1 Characteristics and medical history of male and female patients in both groups

\begin{tabular}{|c|c|c|c|c|c|c|c|c|}
\hline & \multicolumn{4}{|c|}{$\begin{array}{l}\text { Group A } \\
\text { Nalbuphine } 2 \mathrm{mg} / \mathrm{h}\end{array}$} & \multicolumn{4}{|c|}{$\begin{array}{l}\text { Group B } \\
\text { Nalbuphine } 1 \mathrm{mg} / \mathrm{h}\end{array}$} \\
\hline & \multicolumn{2}{|c|}{ Male $($ A1) $(n=32)$} & \multicolumn{2}{|c|}{ Female $(\mathrm{A} 2)(n=32)$} & \multicolumn{2}{|c|}{ Male $(\mathrm{B} 1)(n=32)$} & \multicolumn{2}{|c|}{ Female $(\mathrm{B} 2)(n=31)$} \\
\hline & No & $\%$ & No & $\%$ & No & $\%$ & No & $\%$ \\
\hline \multicolumn{9}{|l|}{ Age } \\
\hline Range (years) & \multicolumn{2}{|l|}{$24-64$} & \multicolumn{2}{|l|}{$18-65$} & \multicolumn{2}{|l|}{$18-64$} & \multicolumn{2}{|l|}{$25-54$} \\
\hline Mean \pm SD & \multicolumn{2}{|c|}{$47.5 \pm 13.6$} & \multicolumn{2}{|c|}{$39.6 \pm 14.0$} & \multicolumn{2}{|c|}{$41.9 \pm 12.2$} & \multicolumn{2}{|l|}{$37.6 \pm 8.2$} \\
\hline Median & \multicolumn{2}{|l|}{49.0} & \multicolumn{2}{|l|}{38.0} & \multicolumn{2}{|l|}{44.0} & \multicolumn{2}{|l|}{35.0} \\
\hline \multicolumn{9}{|l|}{ Weight $(\mathrm{kg})$} \\
\hline Range (years) & \multicolumn{2}{|l|}{$50-100$} & \multicolumn{2}{|l|}{$45-120$} & \multicolumn{2}{|l|}{$65-118$} & \multicolumn{2}{|l|}{$50-120$} \\
\hline Mean \pm SD & \multicolumn{2}{|c|}{$75.6 \pm 10.6$} & \multicolumn{2}{|c|}{$67.6 \pm 16.6^{*}$} & \multicolumn{2}{|c|}{$82.5 \pm 14.3$} & \multicolumn{2}{|l|}{$75.7 \pm 18.9$} \\
\hline Median & \multicolumn{2}{|l|}{75.0} & 64.5 & & 80.0 & & 70.0 & \\
\hline$B M I$ & & & & & & & & \\
\hline Normal $(<25)$ & 16 & 50.0 & 17 & 53.1 & 12 & 37.5 & 9 & 29.9 \\
\hline Overweight $(25-<30)$ & 12 & 37.5 & 12 & 37.5 & 12 & 37.5 & 13 & 41.9 \\
\hline Obese $(30+)$ & 4 & 12.5 & 3 & 9.4 & 8 & 25.0 & 9 & 29.0 \\
\hline Co-morbidity & & & & & & & & \\
\hline Diabetes & 0 & 0.0 & 4 & 12.5 & 3 & 9.4 & 4 & 12.9 \\
\hline Hypertension & 10 & 31.3 & 8 & 25.0 & 10 & 31.3 & 4 & 12.9 \\
\hline CVD & 5 & 15.6 & 1 & 3.1 & 1 & 3.1 & 0 & 0.0 \\
\hline Other & 3 & 9.4 & 1 & 3.1 & 1 & 3.1 & 0 & 0.0 \\
\hline No. of co-morbidities & & & & & 0 & 0.0 & 1 & 3.2 \\
\hline Range & $0-2$ & & $0-3$ & & $0-2$ & & $0-1$ & \\
\hline Mean \pm SD & $0.6 \pm 0.8$ & & $0.4 \pm 0.8$ & & $0.5 \pm 0.7$ & & $0.3 \pm 0.5$ & \\
\hline Median & 0.0 & & 0.0 & & 0.0 & & 0.0 & \\
\hline Medication intake & & & & & & & & \\
\hline Analgesics & 15 & 46.9 & 13 & 40.6 & 9 & 28.1 & 17 & $54.8^{*}$ \\
\hline Hypnotics & 7 & 21.9 & 1 & 3.1 & 1 & 3.1 & 0 & 0.0 \\
\hline Other pain killer & 1 & 3.1 & 0 & 0.0 & 0 & 0.0 & 0 & 0.0 \\
\hline No. of medications & & & & & & & & \\
\hline Range & $0-2$ & & $0-1$ & & $0-1$ & & $0.0-1$ & \\
\hline Mean \pm SD & $0.7 \pm 0.7$ & & $0.4 \pm 0.5$ & & $0.3 \pm 0.5$ & & $0.5 \pm 0.5$ & \\
\hline
\end{tabular}


Table 1 continued

\begin{tabular}{|c|c|c|c|c|c|c|c|c|}
\hline & \multicolumn{4}{|c|}{ Group ANalbuphine $2 \mathrm{mg} / \mathrm{h}$} & \multicolumn{4}{|c|}{ Group BNalbuphine $1 \mathrm{mg} / \mathrm{h}$} \\
\hline & \multicolumn{2}{|c|}{ Male (A1) $(n=32)$} & \multicolumn{2}{|c|}{ Female (A2) $(n=32)$} & \multicolumn{2}{|c|}{ Male (B1) $(n=32)$} & \multicolumn{2}{|c|}{ Female (B2) $(n=31)$} \\
\hline & No & $\%$ & No & $\%$ & No & $\%$ & No & $\%$ \\
\hline Median & 1.0 & & 0.0 & & 0.0 & & 1.0 & \\
\hline
\end{tabular}

$B M I$ body mass index, $C V D$ cardiovascular disease

${ }^{*}$ Statistically significant at $p<0.05$

Adverse events (AEs) associated with the nalbuphine $2 \mathrm{mg}$ administration are shown in Table 6 and 7. There were no statistical gender differences. The most commonly encountered AEs for both genders were sedation, nausea, and vomiting. The most common AEs associated with the nalbuphine $1 \mathrm{mg}$ administration, were sedation, nausea, and vomiting, in addition to dysphoria at 3-h measurement. Female patients experienced significantly more nausea and vomiting as well as sedation at the 6,9 , and 12-h measurement times.

In the multivariate analysis, the higher dose of nalbuphine was a negative predictor for NRS pain scores at the 3- and 6-h measurement times, while the baseline pain score was a positive predictor (Tables 6,7). Female gender in both groups was a negative predictor of the pain score at all four measurement times. Other variables, i.e., age, baseline pain score, and BMI, were nonpredictive.

\section{DISCUSSION}

Gender differences have been reported to influence the perception of pain [16-18], and the efficacy of opioid analgesia [19-22]. In general, women tend to demonstrate lower pain thresholds, less pain tolerance, and higher evoked pain intensity [23-25] as well as reporting higher pain score than men for a given pain condition [20]. However, there are discrepancies between and within previous studies, and gender difference effects only exist for certain types of pain measures $[26,27]$. In addition, some evidence has suggested that gender treatment differences depend on the type of opioid, the characteristics of the studied pain condition, and the treatment modalities, e.g., PCA [28].

KOR agonists have antinociceptive properties [28-30] but with a much lower abuse potential than MOR agonists [31], making them an attractive choice for clinical use, especially in view of the rising alerts concerning opioid abuse.

Mixed KOR/MOR partial agonists, including nalbuphine, pentazocine, and butorphanol, have been shown to produce greater analgesia in women than men in the post-operative dental surgery model $[6,32]$. In a further study, pentazocine provided better analgesia in females for ischemic and thermal pain [33]. In contrast, Fillingim et al. [16] did not report sex differences in the analgesic effects of pentazocine in models of heat, ischemic, and pressure pain. Interestingly, butorphanol produced higher analgesic efficacy in men in the coldwater stimulus pain model [18]. Importantly, clearance of butorphanol has been shown to be lower in women compared to men, raising the possibility that pharmacokinetic differences may play a role $[34,35]$. Finally, studies on gender difference with the use of nalbuphine have been previously scanty and were done with single doses in somatic pain models [6]. Taken together, it is almost impossible to reach a general conclusion about how gender affects pain and analgesia. Therefore, there is a need for more research in this area.

This study has demonstrated that nalbuphine is an efficacious and safe drug in the management of postoperative pain in a human major abdominal surgery model. In the current study, gender effects in the response to nalbuphine for postoperative pain management 
Table 2 Admission data and type of surgery among male and female patients in both groups

\begin{tabular}{|c|c|c|c|c|c|c|c|c|}
\hline & \multicolumn{4}{|c|}{$\begin{array}{l}\text { Group A } \\
\text { Nalbuphine } 2 \mathrm{mg} / \mathrm{h}\end{array}$} & \multicolumn{4}{|c|}{$\begin{array}{l}\text { Group B } \\
\text { Nalbuphine } 1 \mathrm{mg} / \mathrm{h}\end{array}$} \\
\hline & \multicolumn{2}{|c|}{$\begin{array}{l}(\text { A1 }) \\
\text { Male }(n=32)\end{array}$} & \multicolumn{2}{|c|}{ (A2) Female $(n=32)$} & \multicolumn{2}{|c|}{$\begin{array}{l}(\text { B1 }) \\
\text { Male }(n=32)\end{array}$} & \multicolumn{2}{|c|}{$\begin{array}{l}(\mathrm{B} 2) \\
\text { Female }(n=31)\end{array}$} \\
\hline & No & $\%$ & No & $\%$ & No & $\%$ & No & $\%$ \\
\hline \multicolumn{9}{|l|}{ Type of surgery } \\
\hline Hernia repair & 15 & 46.9 & 6 & 18.8 & 13 & 40.6 & 10 & 32.3 \\
\hline Urosurgery & 8 & 25.0 & 8 & 25.0 & 6 & 18.8 & 5 & 16.1 \\
\hline Gastric & 2 & 6.3 & 0 & 0.0 & 2 & 6.3 & 3 & 9.7 \\
\hline Colorectal & 4 & 12.5 & 10 & 31.3 & 6 & 18.8 & 0 & 0.0 \\
\hline Hepatobiliary/pancreatic & 1 & 3.1 & 4 & 12.5 & 1 & 3.1 & 10 & 32.3 \\
\hline Small bowel & 0 & 0.0 & 2 & 6.3 & 3 & 9.4 & 1 & 3.2 \\
\hline Other (splenectomy/omental, etc.) & 2 & 6.3 & 2 & 6.3 & 1 & 3.1 & 2 & 6.5 \\
\hline \multicolumn{9}{|l|}{$A S A$} \\
\hline I & 19 & 59.4 & 23 & 71.9 & 21 & 65.6 & 23 & 74.2 \\
\hline II & 13 & 40.6 & 9 & 28.1 & 11 & 34.4 & 8 & 25.8 \\
\hline
\end{tabular}

Table 3 Baseline pain (time 0) among male and female patients of group A (nalbuphine $2 \mathrm{mg} / \mathrm{h}$ )

\begin{tabular}{lllll}
\hline Gender & & $X^{2}$ & $p$ value \\
test & \\
A1 & A2 & \\
& $(n=32)$ & & $(n=32)$ \\
& No $\%$ & No $\%$ & \\
\hline
\end{tabular}

Pain (time 0)

Mild (1-4) $12 \quad 37.5 \quad 6 \quad 18.8$

$\begin{array}{lllllll}\text { Moderate } & 2 & 6.3 & 2 & 6.3 & 2.86 & 0.24\end{array}$

$(5-7)$

Severe $(8-10) \quad 18 \quad 56.3 \quad 24 \quad 75.0$

Pain score

\begin{tabular}{lllll} 
Range & $2.0-10.0$ & $2.0-10.0$ & & \\
Mean \pm SD & $6.3 \pm 3.1$ & $7.6 \pm 2.6$ & 2.77 & 0.10 \\
$\begin{array}{l}\text { Median } \\
\quad(\mathrm{IQR})\end{array}$ & $8.0(6.0)$ & $8.0(2.0)$ & & \\
\hline
\end{tabular}

Table 4 Baseline pain (time 0) among male and female patients of group B (nalbuphine $1 \mathrm{mg} / \mathrm{h}$ )

\begin{tabular}{llll} 
Gender & & $X^{2}$ & $p$ \\
test & value \\
\hline B1 & B2 & \\
$\begin{array}{c}\text { Male } \\
(n=32)\end{array}$ & $\begin{array}{l}\text { Female } \\
(n=31)\end{array}$ & \\
No \% & No \% &
\end{tabular}

Pain

Mild (1-4) $\quad 11 \quad 34.4 \quad 1 \quad 3.2$

$\begin{array}{lllllll}\text { Moderate } & 3 & 9.4 & 6 & 19.4 & 10.18 & 0.006^{*}\end{array}$

$(5-7)$

Severe (8-10) $18 \quad 56.3 \quad 24 \quad 77.4$

Pain score

Range 2-10 3-10

Mean \pm SD $\quad 6.4 \pm 3.1 \quad 8.1 \pm 1.3 \quad 2.36 \quad 0.12$

Median (IQR) $8.0(6.0) \quad 8.0(1.0)$

*Statistically significant at $p<0.05$ 
Table 5 Total nalbuphine consumption (in $\mathrm{mg}$ ) throughout the study between male and female patients

\begin{tabular}{|c|c|c|c|c|}
\hline \multirow[t]{2}{*}{ Nalbuphine } & \multicolumn{2}{|l|}{ Gender } & \multirow{2}{*}{ Student's $t$ test } & \multirow{2}{*}{$p$ value } \\
\hline & Male & Female & & \\
\hline \multicolumn{5}{|c|}{ Group $A(2 \mathrm{mg} / \mathrm{h})$} \\
\hline Mean \pm SD & $30.91 \pm 3.76$ & $29.03 \pm 2.40$ & 2.384 & $0.020^{*}$ \\
\hline \multicolumn{5}{|c|}{ Group B (1 mg/h) } \\
\hline Mean \pm SD & $25.03 \pm 8.26$ & $20.84 \pm 3.38^{\#}$ & 2.650 & $0.011^{*}$ \\
\hline
\end{tabular}

*Statistically significant at $p<0.05$

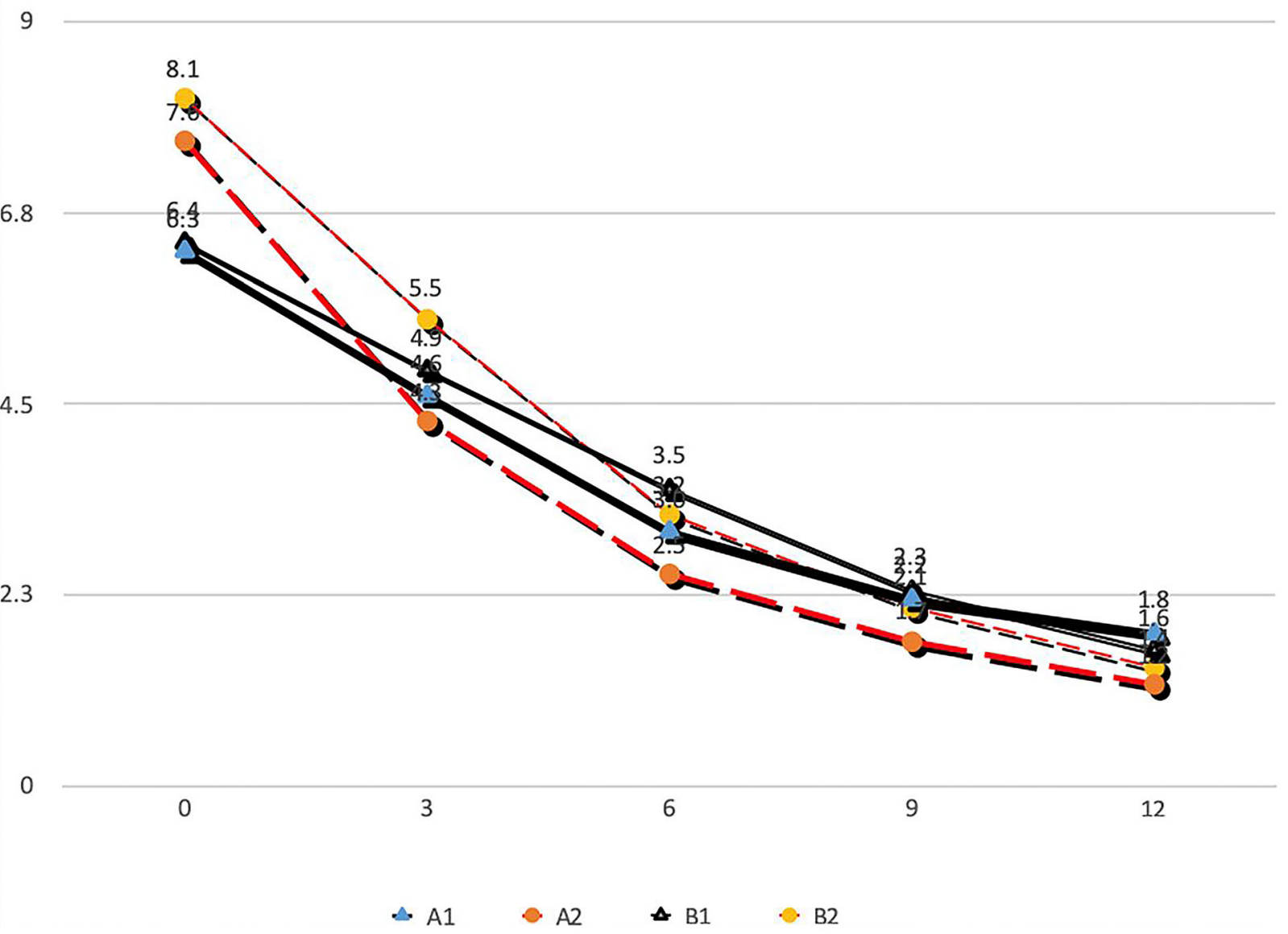

Fig. 2 Numerical pain rating (NPR) scores for all the study groups throughout the study

after major abdominal surgery was investigated. We chose the model of major abdominal surgeries based on basic research that suggests KOR/ MOR heterodimers may play a role in the modulation of the pain experienced in abdominal surgeries.

In this study, in agreement with previous studies $[16,18]$, the baseline pain scores were 
5

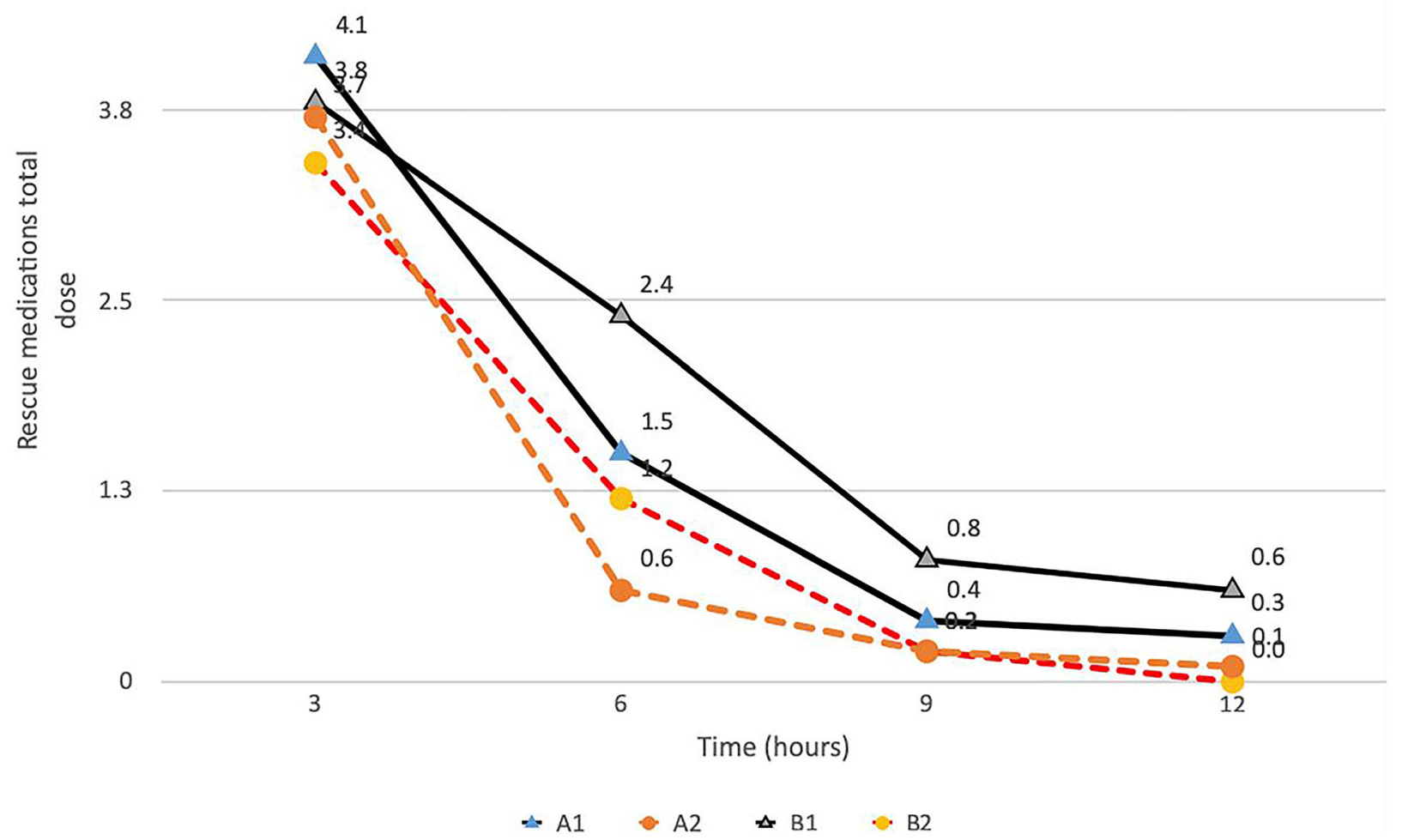

Fig. 3 Total doses of rescue medications by nalbuphine dose $(\mathrm{mg})$ throughout the study

higher in females than males, even if the difference was not statistically significant. There were significant differences in pain scores between genders based on the analgesic response to the two cohorts of nalbuphine infusion (Figs. 2, 3). This response was a dose response with the higher dosing cohort having better analgesia than the lower dosing cohort. Group A2 needed significantly lower doses of rescue nalbuphine compared to males at the 6-h measurement time. However, in the lower dose $(1 \mathrm{mg} / \mathrm{h}$ infusion) treatment group, female patients (group B2) needed significantly lower total doses at the 6-, 9-, and 12-h measurements compared to males (Fig. 3). Therefore, it appears that gender differences were magnified in the lower infusion dose regimen where patients generally needed more rescue nalbuphine. Further, the total nalbuphine consumption by females in our study was significantly lower compared to males in both groups.
The study was carried out in two centers in Egypt, representing a wide variety of the Egyptian population. Dar Al Fouad patients are better educated with a higher average socioeconomic status. The South Valley University Hospital in Qena serves people from villages and rural areas. These subjects tend to have lower average socioeconomic and educational backgrounds. Since pain is subjective and happens within the context of the patients' psychological, social, and intellectual structure, [24] having this diversity of patients was intended to add a broader application to the results.

Even if this study was not powered to quantitatively assess any single AEs, there was a significant higher incidence in females, mostly sedation, nausea, and vomiting (Tab. 3), despite the lower overall nalbuphine consumption, lower number of nalbuphine rescue doses, and lower pain scores. This suggests that the higher 
Table 6 Complications among male and female patients in group A (nalbuphine $2 \mathrm{mg} / \mathrm{h}$ ) throughout the follow-up

\begin{tabular}{|c|c|c|c|c|c|c|}
\hline \multirow[t]{3}{*}{ Complications } & \multicolumn{4}{|c|}{ Gender } & \multirow[t]{3}{*}{$X^{2}$ test } & \multirow[t]{3}{*}{$p$ value } \\
\hline & \multicolumn{2}{|c|}{$\begin{array}{l}\text { A1 } \\
\text { Male }(n=32)\end{array}$} & \multicolumn{2}{|c|}{$\begin{array}{l}\text { A2 } \\
\text { Female }(n=32)\end{array}$} & & \\
\hline & No & $\%$ & $\overline{\text { No }}$ & $\%$ & & \\
\hline \multicolumn{7}{|l|}{$3-h$} \\
\hline Nausea/vomiting & 7 & 21.9 & 11 & 34.4 & 1.24 & 0.27 \\
\hline Dizziness & 5 & 15.6 & 7 & 21.9 & 0.41 & 0.52 \\
\hline Sedation & 7 & 21.9 & 11 & 34.4 & 1.24 & 0.27 \\
\hline Dysphoria & 6 & 18.8 & 9 & 28.1 & 0.78 & 0.38 \\
\hline Hypotension & 1 & 3.1 & 3 & 9.4 & Fisher & 0.61 \\
\hline Bradycardia & 1 & 3.1 & 0 & 0.0 & Fisher & 1.00 \\
\hline \multicolumn{7}{|l|}{ No. of complications } \\
\hline Range & \multicolumn{2}{|l|}{$0-3$} & \multicolumn{2}{|l|}{$0-4$} & & \\
\hline Mean $\pm S D$ & \multicolumn{2}{|c|}{$0.8 \pm 0.9$} & \multicolumn{2}{|c|}{$1.3 \pm 1.1$} & 2.43 & 0.12 \\
\hline Median & \multicolumn{2}{|l|}{1.0} & \multicolumn{2}{|l|}{1.0} & & \\
\hline \multicolumn{7}{|l|}{$6-h$} \\
\hline Nausea/vomiting & 10 & 31.3 & 10 & 31.3 & 0.00 & 1.00 \\
\hline Dizziness & 6 & 18.8 & 7 & 21.9 & 0.10 & 0.76 \\
\hline Sedation & 20 & 62.5 & 26 & 81.3 & 2.78 & 0.10 \\
\hline Dysphoria & 0 & 0.00 & 0 & 0.00 & 0.00 & 1.00 \\
\hline Hypotension & 1 & 3.1 & 1 & 3.1 & Fisher & 1.00 \\
\hline Bradycardia & 2 & 6.3 & 0 & 0.0 & Fisher & 0.49 \\
\hline \multicolumn{7}{|l|}{ No. of complications } \\
\hline Range & \multicolumn{2}{|l|}{$0-3$} & \multicolumn{2}{|l|}{$0-3$} & & \\
\hline Mean $\pm S D$ & \multicolumn{2}{|c|}{$1.2 \pm 1.0$} & \multicolumn{2}{|c|}{$1.4 \pm 0.8$} & 0.39 & 0.53 \\
\hline Median & \multicolumn{2}{|l|}{1.0} & \multicolumn{2}{|l|}{1.0} & & \\
\hline \multicolumn{7}{|l|}{$9-b$} \\
\hline Nausea/vomiting & 9 & 28.1 & 13 & 40.6 & 1.11 & 0.29 \\
\hline Dizziness & 6 & 18.8 & 7 & 21.9 & 0.10 & 0.76 \\
\hline Sedation & 20 & 62.5 & 26 & 81.3 & 2.78 & 0.10 \\
\hline Dysphoria & 2 & 6.3 & 4 & 12.5 & Fisher & 0.67 \\
\hline Bradycardia & 0 & 0.0 & 2 & 6.3 & Fisher & 0.49 \\
\hline \multicolumn{7}{|l|}{ No. of complications } \\
\hline Range & $0-3$ & & $0-4$ & & & \\
\hline
\end{tabular}


Table 6 continued

\begin{tabular}{|c|c|c|c|c|c|c|}
\hline \multirow[t]{3}{*}{ Complications } & \multicolumn{4}{|c|}{ Gender } & \multirow[t]{3}{*}{$X^{2}$ test } & \multirow[t]{3}{*}{$p$ value } \\
\hline & \multicolumn{2}{|c|}{ A1Male $(n=32)$} & \multicolumn{2}{|c|}{ A2Female $(n=32)$} & & \\
\hline & $\overline{\text { No }}$ & $\%$ & $\overline{\text { No }}$ & $\%$ & & \\
\hline Mean \pm SD & \multicolumn{2}{|c|}{$1.2 \pm 1.0$} & \multicolumn{2}{|c|}{$1.6 \pm 1.1$} & 2.87 & 0.09 \\
\hline Median & \multicolumn{2}{|l|}{1.0} & \multicolumn{2}{|l|}{2.0} & & \\
\hline \multicolumn{7}{|l|}{$12-h$} \\
\hline Nausea/vomiting & 7 & 21.9 & 10 & 31.3 & 0.72 & 0.40 \\
\hline Dizziness & 8 & 25.0 & 6 & 18.8 & 0.37 & 0.55 \\
\hline Sedation & 20 & 62.5 & 26 & 81.3 & 2.78 & 0.10 \\
\hline Urine retention & 2 & 6.3 & 0 & 0.0 & Fisher & 0.49 \\
\hline Hypotension & 2 & 6.3 & 4 & 12.5 & Fisher & 0.67 \\
\hline Bradycardia & 0 & 0.0 & 1 & 3.1 & Fisher & 1.00 \\
\hline \multicolumn{7}{|l|}{ No. of complications } \\
\hline Range & \multicolumn{2}{|l|}{$0-4$} & \multicolumn{2}{|l|}{$0-4$} & & \\
\hline Mean $\pm S D$ & \multicolumn{2}{|c|}{$1.2 \pm 1.1$} & \multicolumn{2}{|c|}{$1.5 \pm 1.1$} & 0.65 & 0.42 \\
\hline Median & \multicolumn{2}{|l|}{1.0} & \multicolumn{2}{|l|}{1.0} & & \\
\hline
\end{tabular}

response to nalbuphine and AEs could be attributed to a higher number of KOR/MOR heterodimers in spinal tissue may be affected by the drug. However, until histopathological studies confirm this higher concentration of heterodimers in human spinal tissue, we cannot confirm this hypothesis.

In our multivariate analysis (Table 5), a higher nalbuphine dose was found to be a negative predictor of the pain score at 3- and 6-h measurement times, indicating more drug efficacy that increased by dose. Meanwhile, female gender was a negative predictor of the NRS pain scores at all measurement times, indicating that clinically female gender does respond more efficaciously to this drug (Table 5). In fact, female patients needed significantly less rescue nalbuphine (Fig. 3) and had significantly lower pain scores (Fig. 2). Interestingly, animal studies examining gender differences in pain or analgesic sensitivity have revealed that the presence of gender difference is dependent on the animal model strain chosen for the study $[3,19,36-40]$, although this is not true for every strain [22]. The interactions between gender and genetics on the response to pain and analgesics are still relatively unexplored (especially in humans), but the identification of relevant genes should facilitate development of more effective analgesics for both men and women (Table 8).

In another interesting article, it was postulated that there is a gender dimorphism, at very low doses of nalbuphine, causing a profound anti-analgesic effect due to kappa opioids in males that was managed by increasing the dose up to $10 \mathrm{mg}$ or by combining small doses of a non-selective opioid receptor antagonist naloxone [41]. In our study, we had two infusion rates to test a range of doses given in relation to gender. The multivariate analysis showed that dose is a negative predictor for pain, which means the bigger the dose the better the analgesic effect at 3- and 6-h measurements. However, we did not notice a remarkable change in pain score differences between the very low 
Table 7 Complications among male and female patients of group B (nalbuphine $1 \mathrm{mg} / \mathrm{h}$ ) throughout the follow-up

\begin{tabular}{|c|c|c|c|c|c|c|}
\hline \multirow[t]{3}{*}{ Complications } & \multicolumn{4}{|c|}{ Gender } & \multirow[t]{3}{*}{$X^{2}$ test } & \multirow[t]{3}{*}{$p$ value } \\
\hline & \multicolumn{2}{|c|}{$\begin{array}{l}\text { B1 } \\
\text { Male }(n=32)\end{array}$} & \multicolumn{2}{|c|}{$\begin{array}{l}\text { B2 } \\
\text { Female }(n=31)\end{array}$} & & \\
\hline & $\overline{\text { No }}$ & $\%$ & No & $\%$ & & \\
\hline \multicolumn{7}{|l|}{$3-b$} \\
\hline Nausea/vomiting & 3 & 9.4 & 3 & 9.7 & Fisher & 1.00 \\
\hline Dizziness & 2 & 6.3 & 0 & 0.0 & Fisher & 0.49 \\
\hline Sedation & 2 & 6.3 & 5 & 16.1 & Fisher & 0.26 \\
\hline Dysphoria & 13 & 40.6 & 10 & 32.3 & 0.48 & 0.49 \\
\hline Hypotension & 0 & 0.0 & 1 & 3.2 & Fisher & 0.49 \\
\hline Bradycardia & 0 & 0.0 & 0 & 0.0 & 0.00 & 1.00 \\
\hline \multicolumn{7}{|l|}{ No. of complications } \\
\hline Range & \multicolumn{2}{|c|}{$0-2$} & \multicolumn{2}{|l|}{$0-2$} & & \\
\hline Mean $\pm S D$ & \multicolumn{2}{|c|}{$0.6 \pm 0.6$} & \multicolumn{2}{|c|}{$0.6 \pm 0.6$} & 0.01 & 0.92 \\
\hline Median & \multicolumn{2}{|l|}{1.0} & \multicolumn{2}{|l|}{1.0} & & \\
\hline \multicolumn{7}{|l|}{$6-b$} \\
\hline Nausea/vomiting & 3 & 9.4 & 9 & 29.0 & 3.95 & $0.047^{*}$ \\
\hline Dizziness & 3 & 9.4 & 1 & 3.2 & Fisher & 0.61 \\
\hline Sedation & 13 & 40.6 & 30 & 96.8 & 22.91 & $<0.001^{*}$ \\
\hline Dysphoria & 5 & 15.6 & 0 & 0.0 & Fisher & 0.053 \\
\hline Hypotension & 1 & 3.1 & 2 & 6.5 & Fisher & 0.61 \\
\hline Bradycardia & 0 & 0.0 & 1 & 3.2 & Fisher & 0.49 \\
\hline \multicolumn{7}{|l|}{ No. of complications } \\
\hline Range & \multicolumn{2}{|c|}{$0-2$} & \multicolumn{2}{|l|}{$0-3$} & & \\
\hline Mean \pm SD & \multicolumn{2}{|c|}{$0.8 \pm 0.7$} & \multicolumn{2}{|c|}{$1.4 \pm 0.6$} & 10.76 & $0.001^{*}$ \\
\hline Median & \multicolumn{2}{|l|}{1.0} & \multicolumn{2}{|l|}{1.0} & & \\
\hline \multicolumn{7}{|l|}{$9-b$} \\
\hline Nausea/vomiting & 3 & 9.4 & 11 & 35.5 & 6.21 & $0.01^{*}$ \\
\hline Dizziness & 4 & 12.5 & 2 & 6.5 & Fisher & 0.67 \\
\hline Sedation & 21 & 65.6 & 30 & 96.8 & 9.91 & $0.002^{*}$ \\
\hline Dysphoria & 1 & 3.1 & 2 & 6.5 & Fisher & 0.61 \\
\hline Bradycardia & 1 & 3.1 & 0 & 0.0 & Fisher & 1.00 \\
\hline \multicolumn{7}{|l|}{ No. of complications } \\
\hline Range & $0-3$ & & $0-3$ & & & \\
\hline
\end{tabular}


Table 7 continued

\begin{tabular}{|c|c|c|c|c|c|c|}
\hline \multirow[t]{3}{*}{ Complications } & \multicolumn{4}{|c|}{ Gender } & \multirow[t]{3}{*}{$X^{2}$ test } & \multirow[t]{3}{*}{$p$ value } \\
\hline & \multicolumn{2}{|c|}{$\overline{\text { B1Male }(n=32)}$} & \multicolumn{2}{|c|}{ B2Female $(n=31)$} & & \\
\hline & $\overline{\text { No }}$ & $\%$ & $\overline{\text { No }}$ & $\%$ & & \\
\hline Mean \pm SD & \multicolumn{2}{|c|}{$0.9 \pm 0.9$} & \multicolumn{2}{|c|}{$1.5 \pm 0.7$} & 6.73 & $0.01^{*}$ \\
\hline Median & \multicolumn{2}{|l|}{1.0} & \multicolumn{2}{|l|}{1.0} & & \\
\hline \multicolumn{7}{|l|}{$12-h$} \\
\hline Nausea/vomiting & 4 & 12.5 & 13 & 41.9 & 6.92 & $0.01^{*}$ \\
\hline Dizziness & 6 & 18.8 & 2 & 6.5 & Fisher & 0.26 \\
\hline Sedation & 21 & 65.6 & 30 & 96.8 & 9.91 & $0.002^{*}$ \\
\hline Urine retention & 0 & 0.0 & 0 & 0.0 & 0.00 & 1.00 \\
\hline Hypotension & 3 & 9.4 & 2 & 6.5 & Fisher & 1.00 \\
\hline Bradycardia & 2 & 6.3 & 4 & 12.9 & Fisher & 0.43 \\
\hline \multicolumn{7}{|l|}{ No. of complications } \\
\hline Range & \multicolumn{2}{|l|}{$0-3$} & \multicolumn{2}{|l|}{$0-3$} & & \\
\hline Mean $\pm S D$ & \multicolumn{2}{|c|}{$1.1 \pm 0.9$} & \multicolumn{2}{|c|}{$1.6 \pm 0.8$} & 4.69 & $0.03^{*}$ \\
\hline Median & \multicolumn{2}{|l|}{1.0} & \multicolumn{2}{|l|}{2.0} & & \\
\hline
\end{tabular}

*Statistically significant at $p<0.05$

dose (in the first couple of measurements) and the higher doses in relation to gender.

Finally, some authors have postulated that reproductive hormones such as testosterone and estradiol may modulate the sensitivity to opioid analgesic effects under many-but not all-conditions [40]. Further, the gender difference in the antinociceptive effects of the KOR agonists, have been suggested to be primarily spinal related rather than being supraspinally dependent [42]. All of the above gives a special importance to this current study, since it is the first such study, to our knowledge, investigating the influence of gender in our region and one of the few investigating intravenous use and gender differences.

There are, as with all such studies, limitations that need to be considered. We have not tested the correlation between hormonal changes and drug efficiency nor done any hormonal measurement. This could be considered in further studies. Also, the infused nalbuphine dose was not corrected ideally to body weight. We preferred to follow a simpler protocol of fixed infusion rates plus PCA boluses, as analgesic demands were satisfied via the PCA. We included a variety of abdominal operations, which could also be a confounder. However, all these surgeries contained two elements of pain, somatic and visceral. Theoretically, focusing on just one type of surgical intervention might have been a better model and eliminate some potential bias. In reality, research suggests that patients respond variably to the same surgical stimulus; therefore our goal was to get a variety of surgical trauma carrying the same character, a mixed somato-visceral pain.

\section{CONCLUSIONS}

This study suggests that, while nalbuphine was found to be an effective and well-tolerated analgesic after major abdominal surgery, 
Table 8 Best-fitting multiple linear regression model for the pain score throughout follow-up

\begin{tabular}{|c|c|c|c|c|c|c|c|}
\hline & \multicolumn{2}{|c|}{ Unstandardized coefficients } & \multirow{2}{*}{$\begin{array}{l}\text { Standardized } \\
\text { coefficients }\end{array}$} & \multirow[t]{2}{*}{$t$ test } & \multirow[t]{2}{*}{$p$ value } & \multicolumn{2}{|c|}{$95 \%$ confidence interval for $B$} \\
\hline & $\bar{B}$ & Std. error & & & & Lower & Upper \\
\hline \multicolumn{8}{|l|}{$3-b$} \\
\hline Constant & 3.45 & 0.53 & & 6.536 & $<0.001$ & 2.40 & 4.49 \\
\hline Nalbuphine dose & -0.65 & 0.22 & -0.19 & -2.967 & 0.004 & -1.09 & -0.22 \\
\hline Female gender & -0.47 & 0.23 & -0.14 & -2.068 & 0.041 & -0.92 & -0.02 \\
\hline Baseline pain score & 0.43 & 0.04 & 0.68 & 10.165 & $<0.001$ & 0.35 & 0.51 \\
\hline \multicolumn{8}{|c|}{$r$-square $=0.49$ Model ANOVA: $F=38.89, p<0.001$} \\
\hline \multicolumn{8}{|c|}{ Variables entered and excluded: age, BMI } \\
\hline \multicolumn{8}{|l|}{$6-b$} \\
\hline Constant & 3.85 & 0.49 & & 7.793 & $<0.001$ & 2.87 & 4.82 \\
\hline Nalbuphine dose & -0.54 & 0.21 & -0.22 & -2.619 & 0.010 & -0.95 & -0.13 \\
\hline Female gender & -0.62 & 0.21 & -0.25 & -2.900 & 0.004 & -1.04 & -0.20 \\
\hline Baseline pain score & 0.14 & 0.04 & 0.29 & 3.417 & 0.001 & 0.06 & 0.21 \\
\hline \multicolumn{8}{|c|}{$r$-square $=0.16$ Model ANOVA: $F=7.99, p<0.001$} \\
\hline \multicolumn{8}{|c|}{ Variables entered and excluded: age, BMI } \\
\hline \multicolumn{8}{|l|}{$9-b$} \\
\hline Constant & 2.67 & 0.27 & & 9.907 & $<0.001$ & 2.14 & 3.21 \\
\hline Female gender & -0.41 & 0.17 & -0.21 & -2.387 & 0.018 & -0.75 & -0.07 \\
\hline \multicolumn{8}{|c|}{$r$-square $=0.04$ Model ANOVA: $F=5.70, p=0.018$} \\
\hline \multicolumn{8}{|c|}{ Variables entered and excluded: age, BMI, dose, baseline pain score } \\
\hline \multicolumn{8}{|l|}{$12-h$} \\
\hline Constant & 2.06 & 0.23 & & 9.023 & $<0.001$ & 1.61 & 2.51 \\
\hline Female gender & -0.39 & 0.14 & -0.23 & -2.671 & 0.009 & -0.67 & -0.10 \\
\hline \multicolumn{8}{|c|}{ r-square $=0.05$ Model ANOVA: $F=7.13, p=0.009$} \\
\hline Variables entered an & d exclude & BMI, dose, ba & eline pain score & & & & \\
\hline
\end{tabular}

females were more responsive than males. The difference is more obvious at higher doses and accumulates over time. Further work is needed to confirm if there is a real anatomical difference in the KOR/MOR heterodimer complex in humans as it was shown in animal models. In any case, the knowledge of the presence of a gender difference in response to an opioid drug helps us in optimizing the opioid drug utilization, rendering it particularly appealing for clinical use. 


\section{ACKNOWLEDGEMENTS}

Funding. Our sincere appreciation goes to "Amoun Pharmaceutical", Egypt, which supported this work by supplying the drug (nalbuphine ampoules) as free samples, and the silicone balloon infuser. Also, gratitude goes to the Paolo Procacci Foundation for the support in editing and publishing the results of the research. No Rapid Service Fee was received by the journal for the publication of this article.

Authorship. All named authors meet the International Committee of Medical Journal Editors (ICMJE) criteria for authorship for this article, have contributed to ameliorate the initial draft, take responsibility for the integrity of the work as a whole, and have given their approval for this version to be published.

Authors' Contributions. AEA developed the initial study concept, has drafted the protocol, collected data, and prepared the initial manuscript. OHS, AMFI, and WAMA-T have collected data. AMM has provided all the statistical work.

Disclosures. Amany E. Ayad, Ossama H. Salman, Ahmed Mokhtar Fathy Ibrahim, Waleed A. M. Al-Taher, Adel M. Mishriky, Joseph V. Pergolizzi, Omar Viswanath, Ivan Urits, Martina Rekatsina, John F. Peppin, Antonella Paladini, Giustino Varrassi confirm the absence of any potential conflicts of interest. Giustino Varrassi is the co-Editor-in-Chief of this journal. Joseph V. Pergolizzi, Omar Viswanath, Martina Rekatsina, John F. Peppin, and Antonella Paladini are members of the journal's Editorial Board.

Compliance with Ethics Guidelines. Prior to patients' enrollment, the study was registered at the Pan African Clinical trials Registry with the number PACTR201304000486309, and the study protocol, amendments, and informed consent forms were reviewed and approved by the institutional review boards of both centers [https://www.who.int/clinical-trials-registry-plat form/network/primary-registries/pan-africanclinical-trials-registry-pactr] (Ethical Committee/
Medical council of Dar Al Fouad Hospital, and Ethical Committee of Quena University Hospitals/ South Valley University ID; 5433-03). The study was also conducted in accordance with the Declaration of Helsinki. All patients provided signed informed consent prior to being included in the study. The informed consent included the use of anonymized patient information and data for publication.

Data Availability. The datasets generated during and/or analyzed during the current study are available from the corresponding author on reasonable request. We thank the participants of the study.

Open Access. This article is licensed under a Creative Commons Attribution-NonCommercial 4.0 International License, which permits any non-commercial use, sharing, adaptation, distribution and reproduction in any medium or format, as long as you give appropriate credit to the original author(s) and the source, provide a link to the Creative Commons licence, and indicate if changes were made. The images or other third party material in this article are included in the article's Creative Commons licence, unless indicated otherwise in a credit line to the material. If material is not included in the article's Creative Commons licence and your intended use is not permitted by statutory regulation or exceeds the permitted use, you will need to obtain permission directly from the copyright holder. To view a copy of this licence, visit http://creativecommons.org/licenses/by$\mathrm{nc} / 4.0 /$.

\section{REFERENCES}

1. Varrassi G, Yeam CT, Rekatsina $M$, et al. The expanding role of the COX inhibitor/opioid receptor agonist combination in the management of pain. Drugs. 2020. https://doi.org/10.1007/s40265020-01369-x.

2. Pergolizzi J, Magnusson P, Breve F, et al. Transdermal buprenorphine for acute pain in the clinical setting: a narrative review. J Pain Res. 2021;14: 871-9. https://doi.org/10.2147/JPR.S280572. 
3. Pisanu C, Franconi F, Gessa GL, Mameli S, et al. Sex differences in the response to opioids for pain relief: a systematic review and meta-analysis. Pharmacol Res. 2019;148:104447. https://doi.org/10.1016/j. phrs.2019.104447.

4. Niesters M, Dahan A, Kest B, et al. Do sex differences exist in opioid analgesia? A systematic review and meta-analysis of human experimental and clinical studies. Pain. 2010;151(1):61-8. https://doi. org/10.1016/j.pain.2010.06.012.

5. Gress K, Charipova K, Jung JW, et al. A comprehensive review of partial opioid agonists for the treatment of chronic pain. Best Pract Res Clin Anaesthesiol. 2020;34(3):449-61. https://doi.org/ 10.1016/j.bpa.2020.06.003.

6. Gear RW, Miaskowski C, Gordon NC, et al. The kappa opioid nalbuphine produces gender- and dose-dependent analgesia and antianalgesia in patients with postoperative pain. Pain. 1999;83(2): 339-45. https://doi.org/10.1016/s0304-3959(99)00 119-0.

7. Zhang L, Zhang JT, Hang L, Liu T. Mu opioid receptor heterodimers emerge as novel therapeutic targets: recent progress and future perspective. Front Pharmacol. 2020;11:1078. https://doi.org/10. 3389/fphar.2020.01078.

8. Chakrabarti S, Liu N-J, Gintzler A. Formation of m-/ $\mathrm{k}$-opioid receptor heterodimer is sex-dependent and mediates female-specific opioid analgesia. PNAS. 2010;107(46):20115-9. https://doi.org/10.1073/ pnas. 1009923107.

9. Grundy L, Erickson A, Brierley SM. Visceral pain. Ann Rev Physiol. 2019;81:261-84. https://doi.org/ 10.1146/annurev-physiol-020518-114525.

10. Drewes AM, Olesen AE, Farmer AD, Szigethy E, et al. Gastrointestinal pain. Nat Rev Dis Prim. 2020;6(1): 1-16. https://doi.org/10.1038/s41572-019-0135-7.

11. Rivière PJ-M. Peripheral kappa-opioid agonists for visceral pain. $\mathrm{Br} \mathrm{J}$ Pharmacol. 2004;141(8): 1331-1334. 0705763.

12. Gear RW, Gordon C, Hossaini-Zadeh M, et al. A subanalgesic dose of morphine eliminates nalbuphine anti-analgesia in postoperative pain. J Pain. 2008;9(4):337-41. https://doi.org/10.1016/j. jpain.2007.11.011.

13. Walters SJ, Jaques RM, Dos Anjos H-CIB, Candish J, et al. Sample size estimation for randomized controlled trials with repeated assessment of patientreported outcomes: what correlation between baseline and follow-up outcomes should we assume? Trials. 2019;20(1):566. https://doi.org/10. 1186/s13063-019-3671-2.

14. Varrassi G, Hanna M, Macheras G, et al. Multimodal analgesia in moderate-to-severe pain: a role for a new fixed combination of dexketoprofen and tramadol. Curr Med Res Opin. 2017;33(6):1165-73. https://doi.org/10.1080/03007995.2017.1310092.

15. Falci SG, Marques LS. CONSORT: when and how to use it. J Orthod. 2015;20(3):13-5. https://doi.org/ 10.1590/2176-9451.20.3.013-015.ebo.

16. Fillingim RB, King CD, Ribeiro-Dasilva M, et al. Sex, gender, and pain: a review of recent clinical and experimental findings. J Pain. 2009;10(5):447-85. https://doi.org/10.1016/j.jpain.2008.12.001.

17. Boerner KE, Chambers CT, Gahan J, et al. Conceptual complexity of gender and its relevance to pain. Pain. 2018;159(11):2137-41. https://doi.org/10. 1097/j.pain.0000000000001275.

18. Kimberly TS, Lindsay LK, Glover TL, et al. Individual differences in morphine and butorphanol analgesia: a laboratory pain study. Pain Med. 2011;12(7):1076-85. https://doi.org/10.1111/j. 1526-4637.2011.01157.x.

19. Fillingim RB, Ness TJ, Glover TL, et al. Experimental pain models reveal no sex differences in pentazocine analgesia in humans. Anesthesiology. 2004;100(5):1263-70. https://doi.org/10.1097/ 00000542-200405000-00031.

20. Zacny JP, Beckmann NJ. The effects of a cold-water stimulus on butorphanol effects in males and females. Pharmacol Biochem Behav. 2004;78(4): 653-9. https://doi.org/10.1016/j.pbb.2004.01.021.

21. Bodnar RJ, Kest B. Sex differences in opioid analgesia, hyperalgesia, tolerance and withdrawal: central mechanisms of action and roles of gonadal hormones. Horm Behav. 2010;58(1):72-81. https:// doi.org/10.1016/j.yhbeh.2009.09.012.

22. Rasakham K, Liu-Chen LY. Sex differences in kappa opioid pharmacology. Life Sci. 2011;88(1-2):2-16. https://doi.org/10.1016/j.lfs.2010.10.007.

23. Craft RM. Sex differences in analgesic, reinforcing, discriminative, and motoric effects of opioid. Exp Clin Psychopharmacol; 2008;16(5):376-85. https:// doi.org/10.1037/a0012931.

24. Riley JL 3rd, Hastie BA, Glover TL, Fillingim RB, et al. Cognitive-affective and somatic side effects of morphine and pentazocine: Side-effect profiles in healthy adults. Pain Med. 2010;11(2):195-206. https://doi.org/10.1111/j.1526-4637.2009.00680.x. 
25. Nasser SA, Afify EA. Sex differences in pain and opioid mediated antinociception: modulatory role of gonadal hormones. Life Sci. 2019;237:116926. https://doi.org/10.1016/j.lfs.2019.116926.

26. Berkley KJ. Sex differences in pain. Behav Brain Sci. 1997;20(3):371-80. https://doi.org/10.1017/ S0140525X97221485.

27. Weisenfeld-Hallin Z. Sex differences in pain perception. Gend Med. 2005;2(3):137-45. https://doi. org/10.1016/S1550-8579(05)80042-7.

28. Bartley EJ, Fillingim RB. Sex differences in pain: A brief review of clinical and experimental findings. Br J Anaesth. 2013;111(1):52-8. https://doi.org/10. 1093/bja/aet127.

29. Tejeda HA, Bonci A. Dynorphin/kappa-opioid receptor control of dopamine dynamics: implications for negative affective states and psychiatric disorders. Brain Res. 2019;1713:91-101. https://doi. org/10.1016/j.brainres.2018.09.023.

30. Dunn A, Windisch K, Ben-Ezra A, Pinkus P, et al. Modulation of cocaine-related behaviors by low doses of the potent KOR agonist nalfurafine in male C57BL6 mice. Psychopharmacology. 2020;237(8): 2405-18. https://doi.org/10.1007/s00213-02005543-7.

31. Kaski SW, White AN, Gross JD, Siderovski DP. Potential for kappa-opioid receptor agonists to engineer nonaddictive analgesics: a narrative review. Anesth Analg. 2021;132(2):406-19. https:// doi.org/10.1213/ANE.0000000000005309.

32. Gear RW, Gordon NC, Heller PH, et al. Gender difference in analgesic response to the kappa-opioid pentazocine. Neurosci Lett. 1996;205(3):207-9. https://doi.org/10.1016/0304-3940(96)12402-2.

33. Mogil JS, Wilson SG, Chesler EJ, et al. The melanocortin-1 receptor gene mediates female-specific mechanisms of analgesia in mice and humans. Proc Natl Acad Sci USA. 2003;100(8):4867-72. https:// doi.org/10.1073/pnas.0730053100.

34. Sibille KT, Kindler LL, Glover TL, et al. Individual differences in morphine and butorphanol analgesia: a laboratory pain study. Pain Med. 2011;12(7):1076-85. https://doi.org/10.1111/j. 1526-4637.2011.01157.x.

35. Santangelo B, Micieli F, Marino F, Reynaud F, et al. Plasma concentrations and sedative effects of a dexmedetomidine, midazolam, and butorphanol combination after transnasal administration in healthy rabbits. J Vet Pharmacol Ther. 2016;39(4): 408-11. https://doi.org/10.1111/jvp.12282.

36. Le Bars D, Gozariu M, Cadden SW. Animal models of nociception. Pharmacol Rev. 2001;53(4):597-652 (PMID: 11734620).

37. Barrett AC, Cook CD, Terner JM, et al. Importance of sex and relative efficacy at the mu opioid receptor in the development of tolerance and cross-tolerance to the antinociceptive effects of opioids. Psychopharmacol. 2001;158(2):154-64. https://doi. org/10.1007/s002130100821.

38. Negus SS, Mello NK. Effects of gonadal steroid hormone treatments on opioid antinociception in ovariectomized rhesus monkeys. Psychopharmacology. 2002;159(3):275-83. https://doi.org/10. $1007 / \mathrm{s} 002130100912$.

39. Sternberg WF, Smith L, Scorr L. Nociception and antinociception during the first week of life in mice: sex differences and test dependence. J Pain. 2004;5(8):420-6. https://doi.org/10.1016/j.jpain. 2004.07.002.

40. Stoffel EC, Ulibarri CM, Folk JE, et al. Gonadal hormone modulation of mu, kappa, and delta opioid antinociception in male and female rats. J Pain. 2005;6(4):261-74. https://doi.org/10.1016/j.jpain. 2004.12.006.

41. Gear RW, Gordon NC, Miaskovski C, et al. Sexual dimorphism in very low dose nalbuphine postoperative analgesia. Neurosci Lett. 2003;339(1):1-4. https://doi.org/10.1016/s0304-3940(02)01438-6.

42. Craft RM, Bernal SA. Sex differences in opioid antinociception: kappa and "mixed action" agonists. Drug Alcohol Depend. 2001;63(3):215-28. https://doi.org/10.1016/s0376-8716(00)00209-x. 